\title{
The Study of Factors Related to Employment
}

\section{MSC. Doreta Tartari ( Kuçi )}

\author{
Department of Sociology \\ University "Aleksandër Moisiu" Durrës \\ doretataratari@yahoo.it
}

\section{Doi:10.5901/mjss.2013.v4n4p409}

\begin{abstract}
The study aims to give us a clear information about the factors that are directly related to the problems of women's employment in the informal area of Durres, former swamp. To carry out this study it was used the quantitative research method. The main instrument used for data collection was a questionnaire clear developed and it contents questions related to the problem. Questionnaire has in its content: - Demographic data: age, marital status, educational level, family size, religious affiliation and previous residence and number of years living in the area of the former swamp. - Data on employment, leisure and income. - Data on education. The study also includes a range of problems that affect employment.
\end{abstract}

Keywords: Women, Employment Issues, Education, Factors.

\section{Introduction}

The area of "Former-Marshes" in Durrres still remains one of the most problematic areas of the city. Among ather problems related to this ars, the women's employment is also a very concerning problem and almost not solve dat all due to a lot of reasons such as: lack of information, education, and necesaary qualifications, lack of available jobs, social isolation, the family's mentality, lack of elderly and small children's care service etc.

Disconnected from their former residence (well-structured cities or towns)and with different mentalities, these people found themselves in front of the unknown, instabiliyu and anonymity.

The geopgraphical composition of the newcomers is diversified but those that come from the north of Albania, forced by the difficulties of the living consditions, lack of infields, unemployment, poverty and climatic conditions, constitute the greatest number of them.

The newcomers are mainly from cities such as: Bulqizë, Mirditë, Pukë, Kukës, Tropojë, Gramsh, Peshkopi, Dibër e Malësi e Madhe, etc.

\section{Data analysis}

\subsection{Descriptive analysis of the data}

To perform this study uses quantitative research method. The main instrument used for data collection was a questionnaire designed in such a way to provide information on the following aspects:

- Demographic data such as: age, marital status, educational level, family size, religious affiliation and previous residence and number of years living in the area of the former swamp.

- Data on employment, leisure and income: The purpose of this group of questions is to assess the level of participation of women in the area in the labor market, taking their economic interdependence seen as an indication of the monthly personal income for employed women and family income for all women regardless of their employment status. On the other hand questions about the number of hours women spend, to take care of children, household work (unpaid) or to work outside the home, helping to establish a more complete picture of the position of women in the family and in society.

- $\quad$ Data on education: In this section, the questions are designed such that it can provide an indirect assessment of the factors that affect the level of education of women, focusing primarily on the adequacy or inadequacy of 
the educational level of women in reality, and after receiving the information about who is responsible for the education of women (as they are competent to decide for themselves) then moved on to the question of where women say who plays the leading role in the family to promote the education of children.

- Data on violence against women: In this section the questions relate to factors that promote violence against women

- Information on issues of women's decision-making. The purpose of this section is to assess questions of strengthening the role of women in the family and later and in society.

- Information on health service: This set of questions deals information for the right of women to obtain health insurance and women's opinions about who is responsible for improving the health service to them.

- The final section of the questionnaire is an open question where are women's opinions regarding the improvement of life in the area of the former swamp.

Questions are structured, unstructured, and in some cases also in the form of measuring scales.

\subsection{Selection of the sample}

As a basis for the selection of the sample was used the most recent data the Municipality of Durres, where it appears that the former swamp area are about 9,000 households and about 45,000 inhabitants. Women make up 49 percent of the population residing in the area of the former swamp. While women aged 16 years and older represent approximately 72 percent of female resident population. For former swamp area is not yet created a statistical database as a civil registry or a system address. For this reason, the sample selection was made using a systematic probability of selection.

Primary statistical units surveyed are former swamp area families which were selected by systematic probability method, interviewing so one in seven families. Later in the selected households were interviewed one of the women aged 16 years and older who was a member of the family and was found there at the time of the survey. In cases where the family when they were interviewing two or more women, then interviewed the woman who was resident in the family and was available to answer questions of the questionnaire. There was no interview to the women who were guests in the family at the time of interview.

To obtain a sample which can be used to obtain results representative of the area, 648 households were selected from which 631 of them, the questionnaire was completed. So the participation rate in the survey was 97.4 percent. Interviews were conducted between January - April 2012.

The main hypothesis we raise in this study is that the participation of women in the labor market strongly influenced by social factors, such as social empowerment of women, (the decision-making power in the family)

\subsection{Descriptive analysis of the data}

\subsubsection{Family Size}

Household size is an important factor that affects directly in many aspects related to the degree of participation of women in the labor market, their educational level, with decision-making power of women in the family, etc.. Figure 2 presents the distribution of respondent households by household size. Note that slightly more than a quarter of the interviewed households are families consisting of 5 members. Families with 8 or more members make up 6 percent of the families interviewed. 
Table 2: Respondents distribution by household size

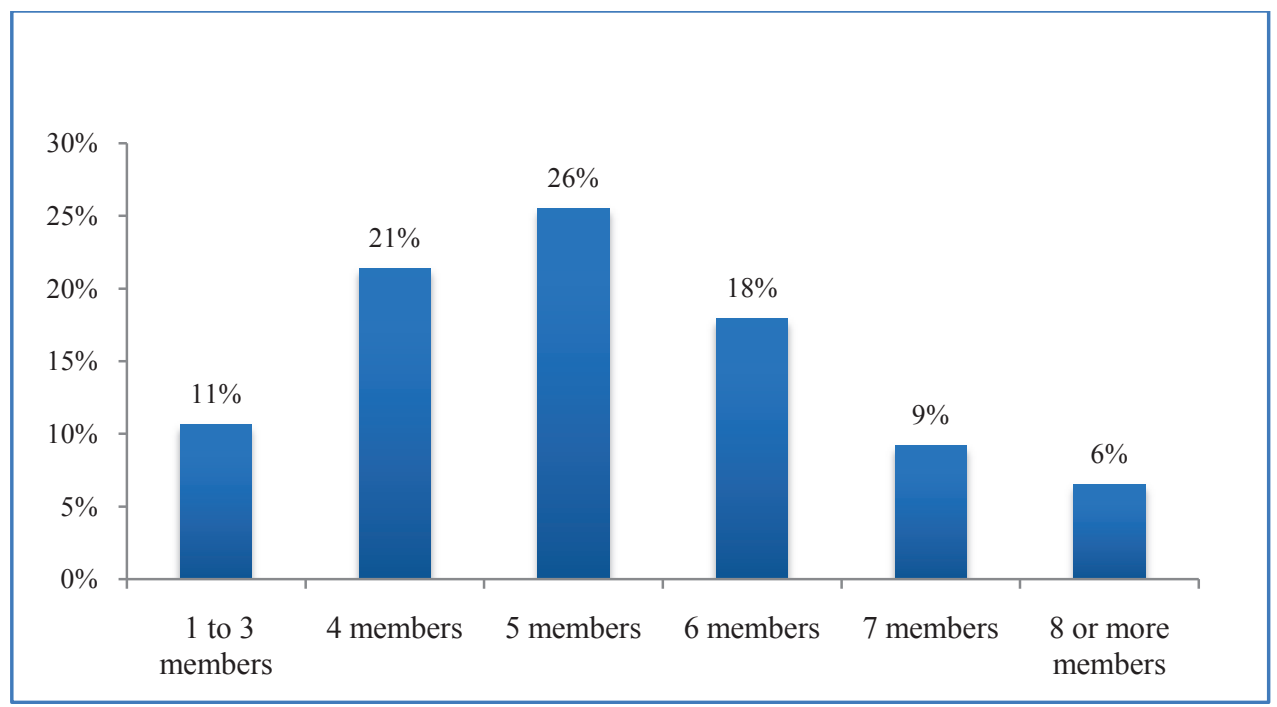

\section{Previous residence and years of residence in the area of the former swamp}

A determining factor for the involvment of women in social life and in the labor market is related to the traditions and culture of their country of origin. In the years of transition, internal migration got big. Durrës became the second most attractive areas after Tirana migrants from Albania districts. According to 2011 Census Durres had more than 18 percent of the migrants (44900). One of the greatest difficulties that led to internal migration was and continues to be a process of integration of immigrants.

\section{Table 3: Respondets distribution by number of years that were settled in Këneta}

(How many years ago did you come to live in this area?)

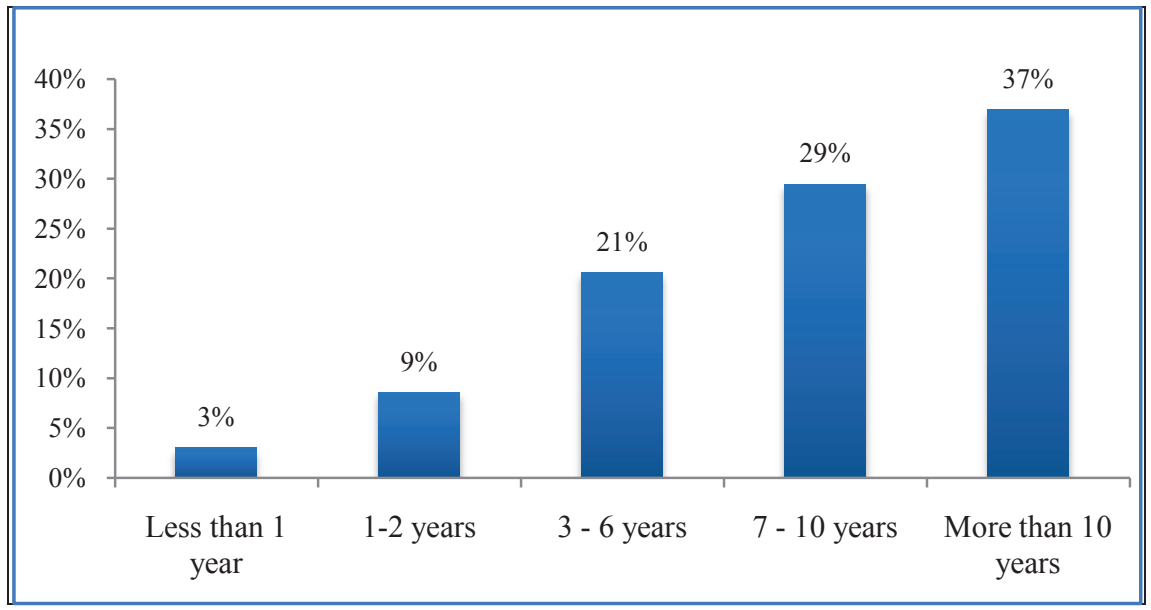

At former swamp area, 37 percent of the families interviewed have immigrated more than 10 years, while 29 percent of them are located in this area in the years 2008-2012. Most families come from the districts of Dibër Region, Kukësit, Beratit, Korçës, and Pukë. 


\section{Graph: Respondent distribution by geographical origin area}

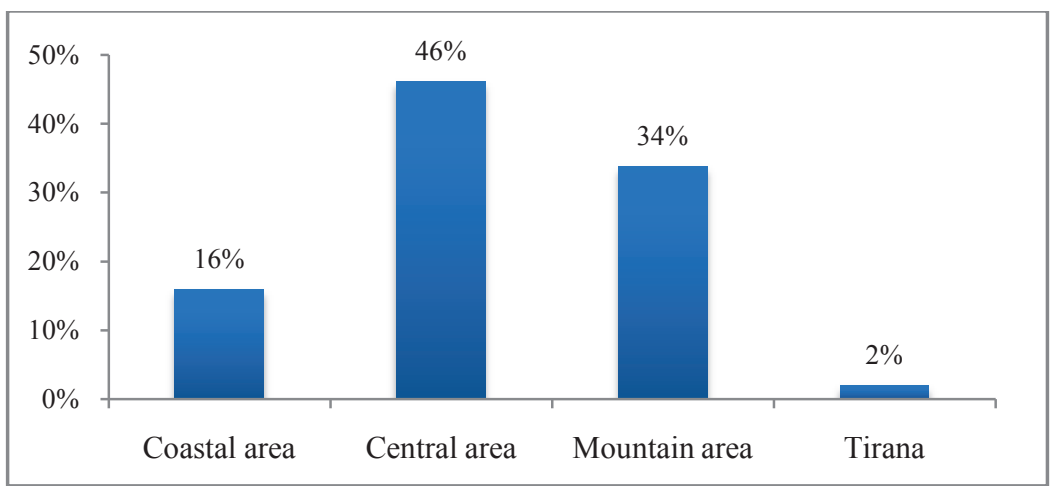

If we refer to four main geographical areas of our country, it turns out that 46 percent of households from the central area of Albania, while 34 percent come from mountainous areas. Come from coastal areas are 16 percent of households. Composition of the four geographical areas by districts was as follows: Coastal Zone: Delvin, Durres, Fier, Kavaja, Lac, Lezha, Lushnje, Mallakastër, Saranda, Vlore. Central Zone: Berat, Devoll, Elbasan, Gjirokastra, Kolon je, Korca, Kruja, Kuçovë, Malesi e Madhe, Mat, Mirdita, Peqin, Permet, Pogradec Puke, Shkodër, Skrapar, Tepelenë Mountain Zone: Bulqizë, Diber, Gramsh, Has, Kukes, Librazhd, Tropojë. Tirana: Tirana (urban and rural zone).

\section{Marital status}

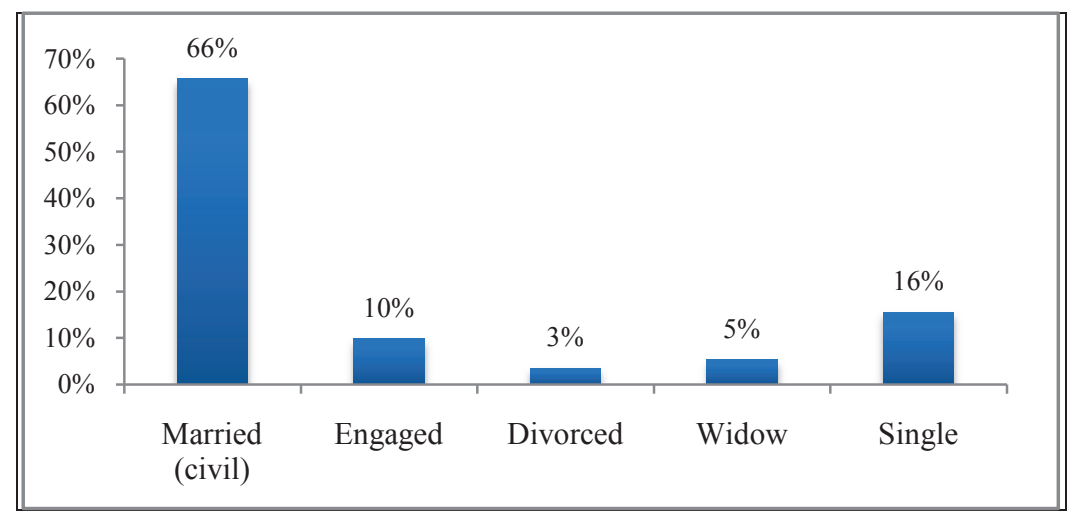

Regarding the situation of women, the results of the study, 66 percent of the women interviewed were married, 16 percent single and 3 percent were divorced.

\section{Religious affiliation}

In the former swamp area, 72 percent of the women interviewed stated that they are of Muslim faith, while 16 percent of them belong to the Catholic Christian faith. While 7 percent of women stated that belong to Bektashi belief versus 3 percent are Orthodox Christian faith. It should be noted that the question made to the women about their religious affiliation does not make a distinction between religion that women believe or feel that they belong and practicing it. 


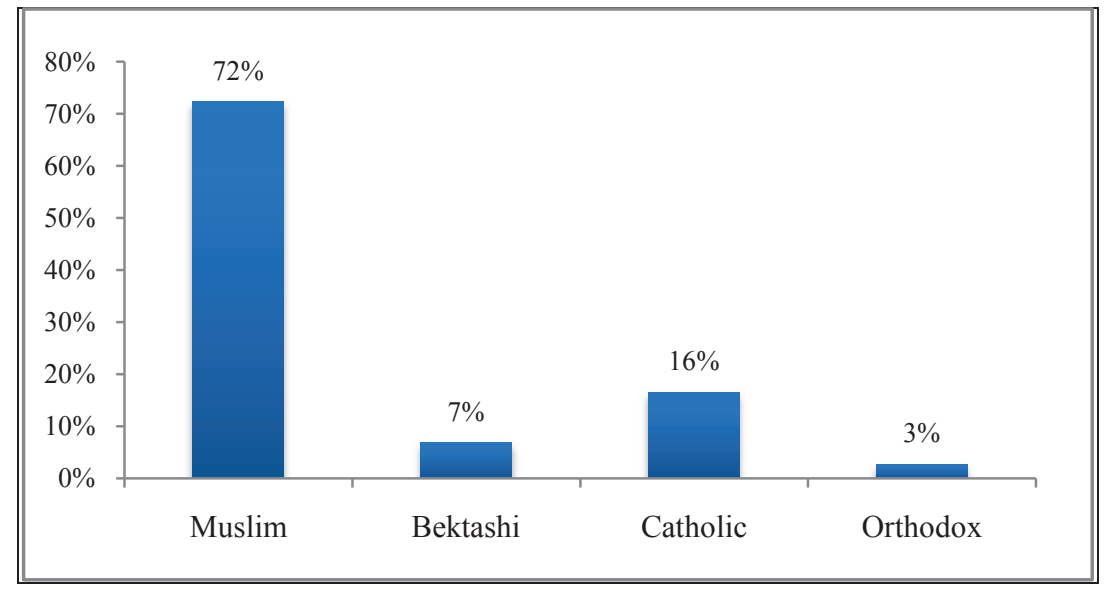

If asked which of practicing religion, then the distribution given in the chart above will reflect more accurately the division of the study population according to religious affiliation. However, 1.2 percent of the women interviewed preferred not to give an answer to this question.

\section{Education of women}

XX graph presents the distribution of women interviewed by education level and age. What stands out is that with increasing age completed education level tends to primary education, while the 16-24 years age group 39.3 percent of women with secondary education and 34.7 percent are highly educated.

\section{Graph XX: Distribution of the sample by education level and age}

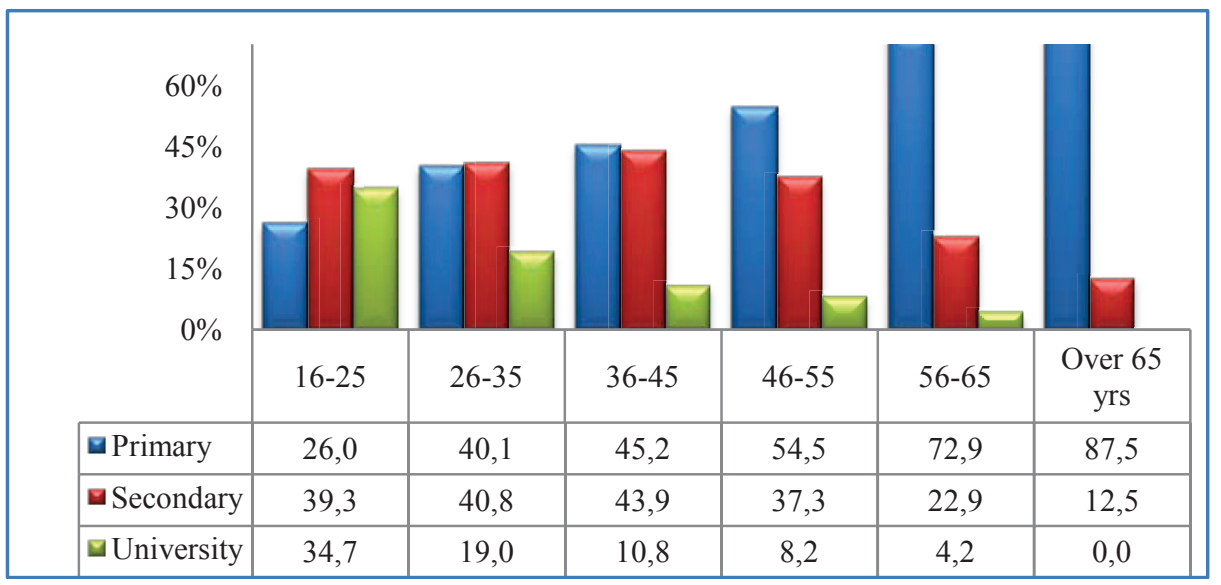

Source: Analysis of Privacy (2012)

From the women interviewed, 71.2 percent of them want a better level of education, while 20.7 percent of them claim that their educational level is sufficient and only 9.1 percent of them did not provide an answer to this question. Three-quarters of women with primary education want to have a better educational level also 79 percent of women with secondary education want this. The lower the educational level, the more employment opportunities reduce for women. Of women with higher 58.4 percent think that their educational level is sufficient, while about 35 percent of them want a better level of education. 
Table 2: Distribution of the women interviewed by education level and desired level of education completed.

\begin{tabular}{lllll}
\hline & Sufficient education & $\begin{array}{l}\text { Want a better educational } \\
\text { level }\end{array}$ & No answer & Total \\
\hline Educational level & & & & \\
Primary & 11.6 & 75.4 & 13.0 & 100 \\
Secondary & 15.3 & 79.2 & 5.5 & 100 \\
University & 58.4 & 34.7 & 6.9 & 100 \\
Total & 20.7 & 70.1 & 9.1 & 100 \\
\hline
\end{tabular}

Which of the following actors do you think is more responsible for your education?

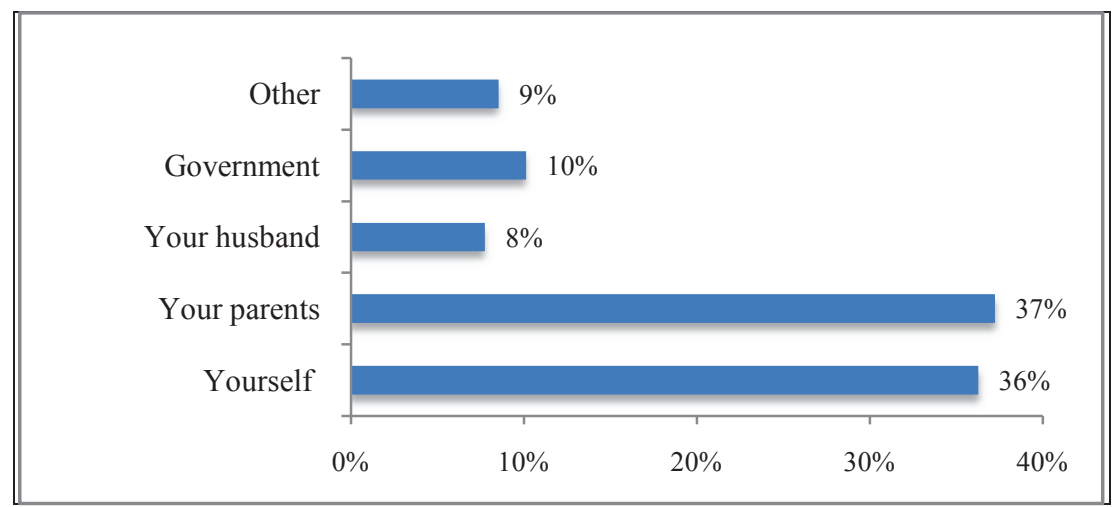

More than a third of the women interviewed think that parents are the most responsible actors for their education, and 36 percent of women stated that they are responsible for the education itself. In ten women believe that the actor more responsible for their education is the state, while 8 per cent of women think that the husband is responsible actor. But about 9 percent of women responded that there are other factors that affect their education. Among them, the main factor is the economic situation and the long distance between the school and the location.

To encourage children to be educated both parents play the main role together. But 14 percent of women think that the mother plays a primary role in encouraging children to be educated, compared to 4 percent who think that the father plays a major role.

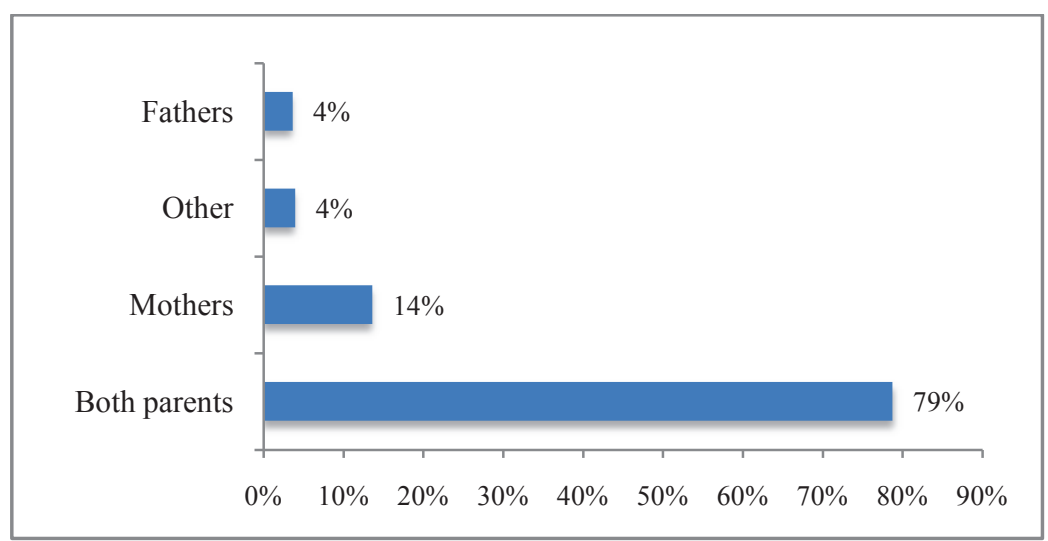


About 4 percent of women believe that state plays a major role in encouraging children to get an education, society and the tendency or self ambition of the children to be educated.

\section{Violence against women}

In the section of questions on violence against women, 51 percent of the women interviewed stated that they had never felt abused, while more than a fifth of them stated that they felt sometimes abused. But 4 percent of the women interviewed claimed that feel constantly violated. Taking into consideration that the violence questions are sensitive and in many cases women are reluctant to talk and to admit it, the answers may not be completely true. Here about 13 percent of women gave no answer to this question, but they gave their views on the factors that could cause violence.

Graph: Violence against women

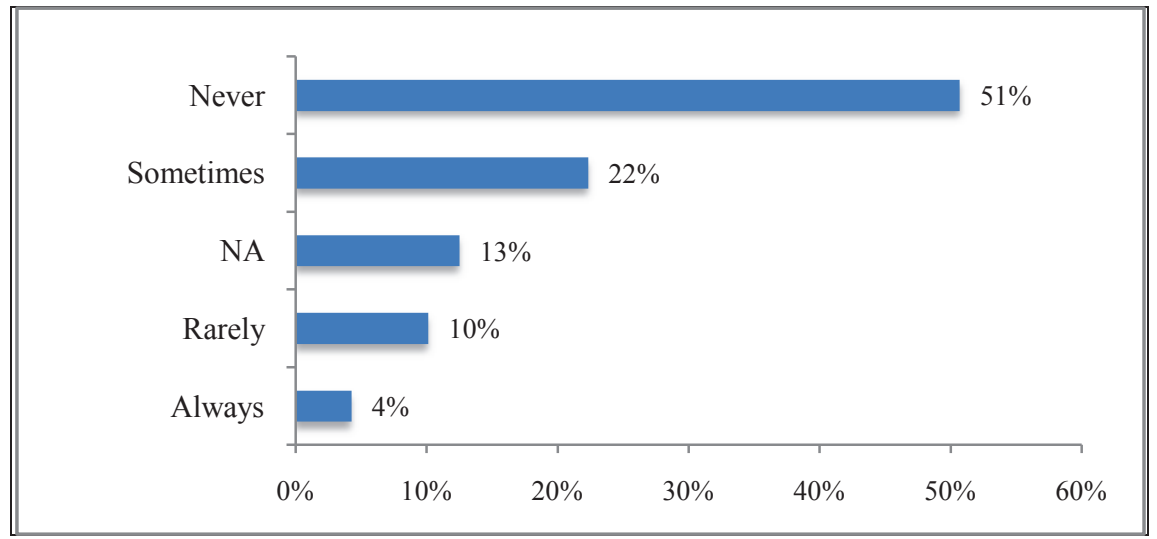

Questions in this section are not divided in categories of types of violence (physical, psychological, sexual, etc.), but talk about violence in general. About one-fifth of the women interviewed think that vices like jealousy, alcohol and gambling are the cause of violence against women. Low economic level is another causal factor of violence (17 percent). 16 percent of women believe that unemployment increases the probability of being raped. But more than a third of women think that violence against women is caused by a combination of factors together (unemployment, addictions, low economic growth, low levels of education).

Graph: Factors that cause violence

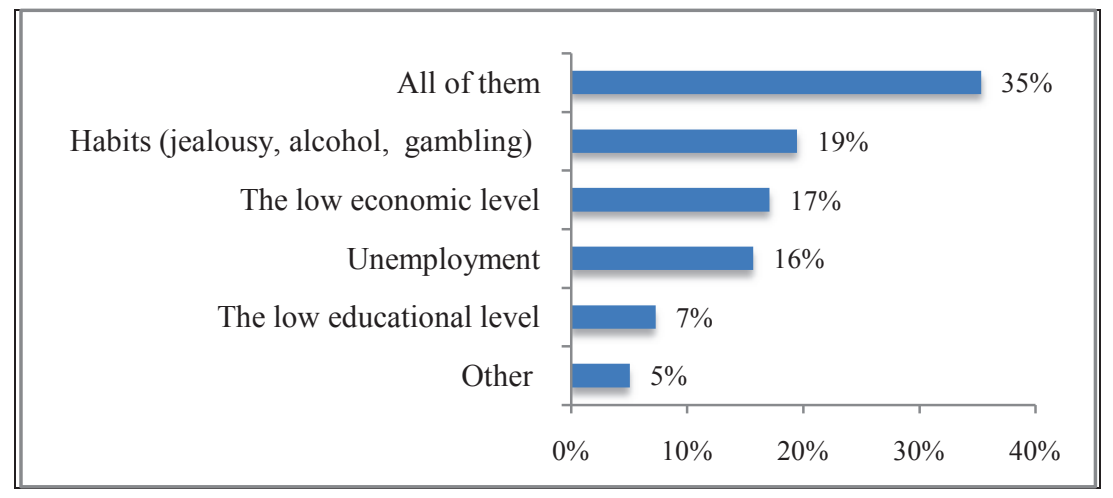

From the graph above we note that 5 percent of women think that there are other factors that cause violence toward them. If we take a general look at the graph we see that they agree on low economic level. Also if we focus on the group 
of the women that didn't give any answer if they ever felt abused, about 35 percent think that violence is coused at least once from these factors all together (unemployment, vices, low economic level, low educational level).

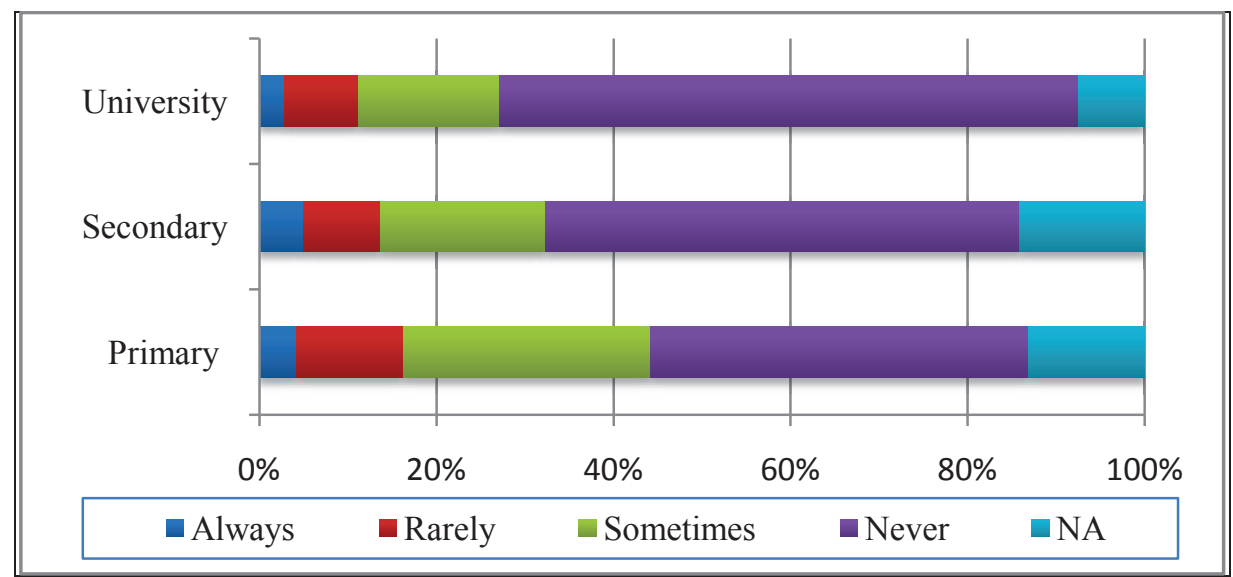

The analysis of violence by level of education, noted that women with higher education 16 percent of them ever feel abused, and 65 percent of respondents stated that they never feel violated. Of women with secondary education 19 percent of them feel ever abused, and 5 percent of them agreed that chronically abused. But 14 percent of women with secondary education preferred not to answer this question.

But what stands out from the chart above is the fact that women with primary education are more exposed to violence than women with higher education. 28 percent of women with $8 / 9$ years old said they sometimes feel abused, while 43 percent of respondents stated that they never feel violated.

\section{Issues of women's decision-making}

In this section, questions related to women-led decision-making power of women in the family.

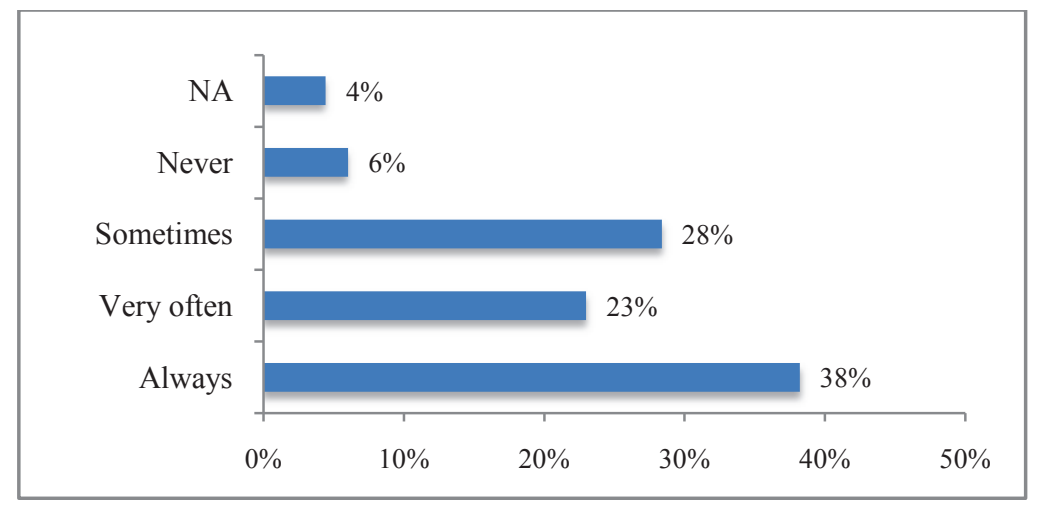

Question when considering women thought about the family's financial affairs, 38 percent of women answered always considered their opinion. However, 28 percent of women ever participate in decision-making on financial matters, and 6 percent are completely excluded from this type of decision-making. 


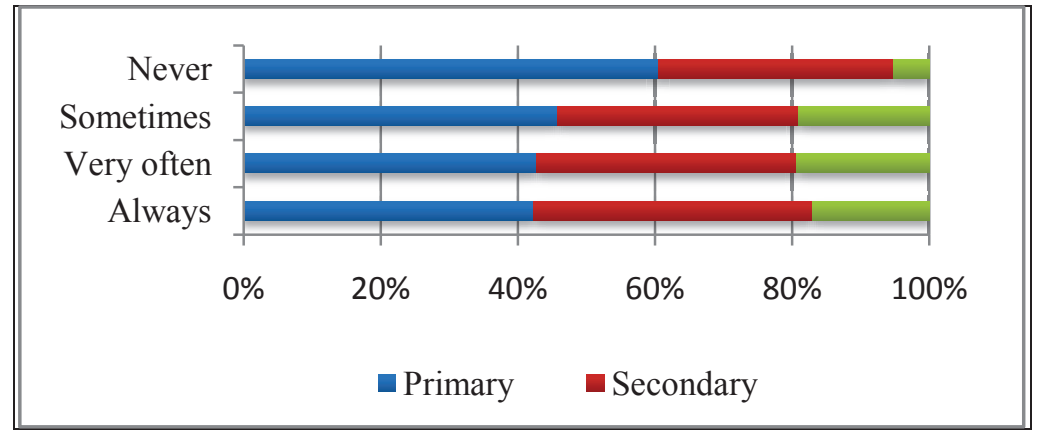

By women who are always involved in decision-making related to family financial issues, 17 percent have higher education, 42 percent in primary education and 41 percent with secondary education. While women who are excluded from this type of decision-making, $5 \%$ are highly educated, and 61 percent have primary education.

Participation of women in decision-making in the family for 64 percent of the women interviewed is very important and 29 percent think it is important.

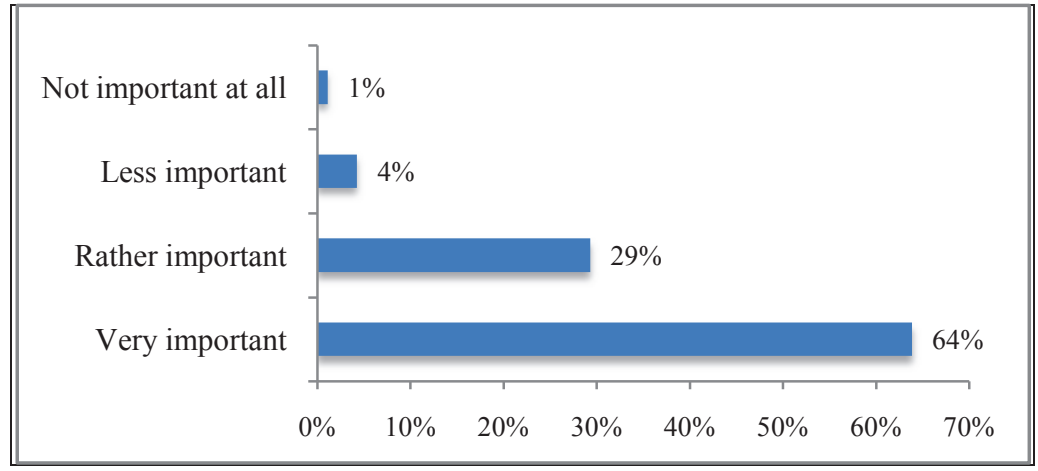

Only 5 percent of the women interviewed think that the participation of women in decision-making in the family is a little or not at all important.

Regarding the decision of childrens fate , 5 of the 10 women interviewed said they always consider their views within the family decisions about the fate of children. 17 percent of the women intervied gave no answer to this, whose marital status was either single or engaged. While 4 percent of respondents stated that they never take into account their opinion about the fate of children.

Chart: Do you consider your opinion on decisions within the family about the fate of the children?

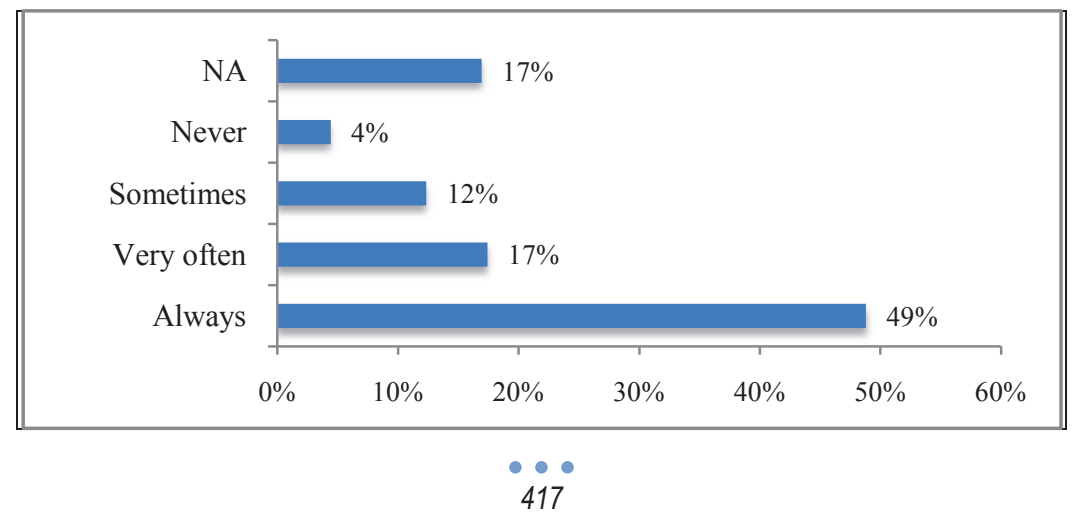


A series of questions were led women to assess that take into account their views on the place of residence, their employment, childbearing, child-rearing and household income. The table XX ne aneks YY summarized responses of the women interviewed. Associated with the birth of children, 63 percent of women stated that they considered their opinion. In 6 of the 10 women whose ever taken into account the opinion of the decisions within the family about the fate of children, considering the outlook for growth. But 17 percent of women stated that they were not taken into account for children's thinking despite the fact that they were ever taken into account the opinion of the decisions within the family about the fate of children.

Graph: Thinking about raising children according to children's fate

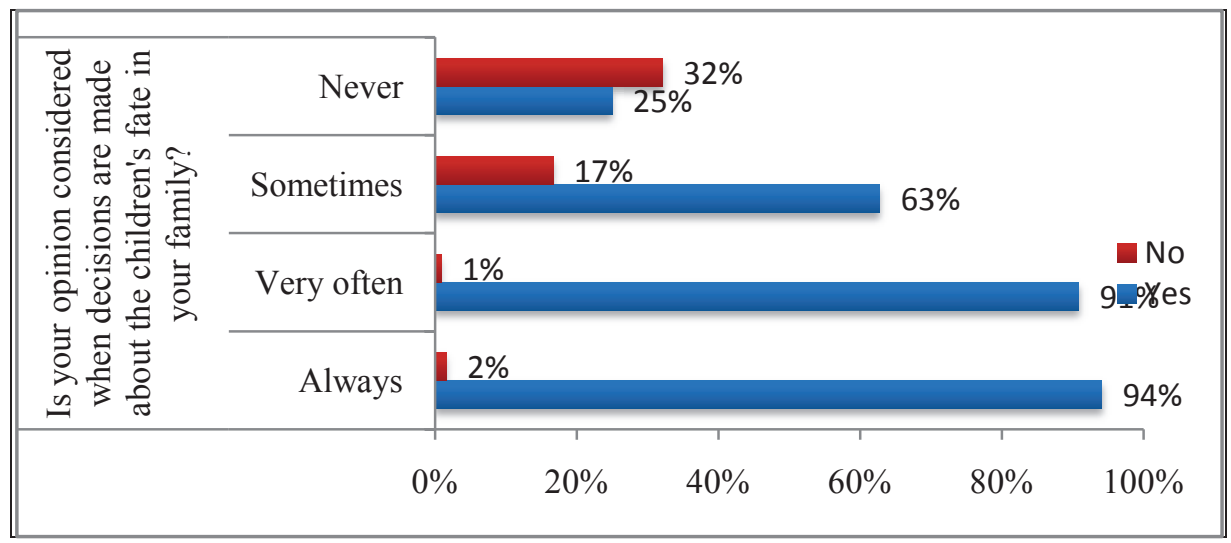

While 1 in 4 women are completely excluded from the decision-making concerning the fate of the children were taken into consideration for raising their children. Women who always or often decision-making power over the fate of the children, was also considered their opinion and to raise children as well as their birth.

\section{Health service}

Asked if they receive health insurance from the state 68 percent of women answered no. Whereas, if we consider the educational level of women, for the three levels analyzed more than half of women do not benefit from health insurance.

Graph: The benefit of health insurance according to educational level

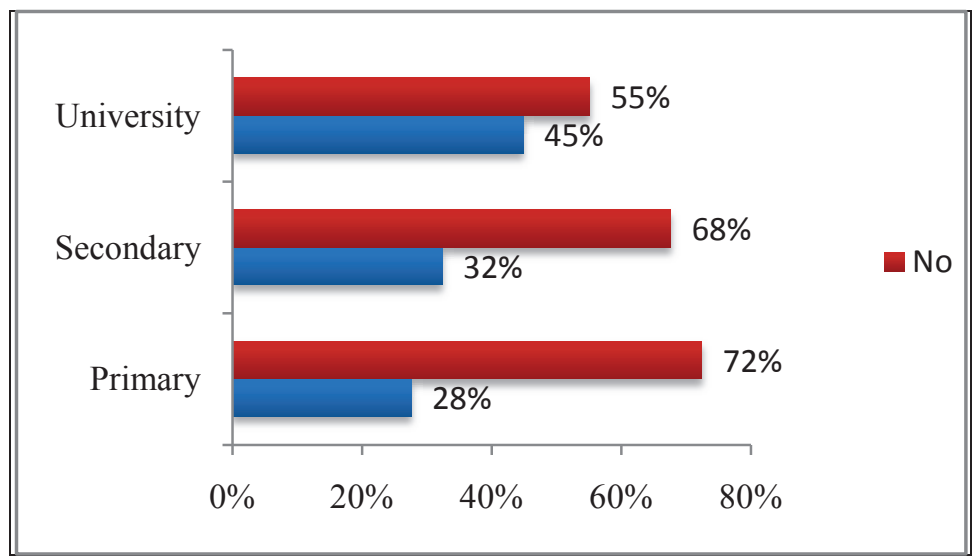


But from employed women only 5 to 10 women benefit from the state health insurance. If we look at the employment status of women, 68 percent of women employed in the public sector, 55 percent of women employed in the private sector and 30 percent of self-employed women stated that they benefit from health insurance from the state.

From the XX chart below, we see that one in four women who do not receive health insurance from the state, give as the main reason to distrust doctors. But 42 percent of this category stated that the main reason that prevents them from receiving health services is the lack of information. Distance from health center is the main obstacle for the benefit of health insurance, to 16 percent of women, while a small percentage of women ( 3 percent) stated as the main reason Kanun (canon) habits.

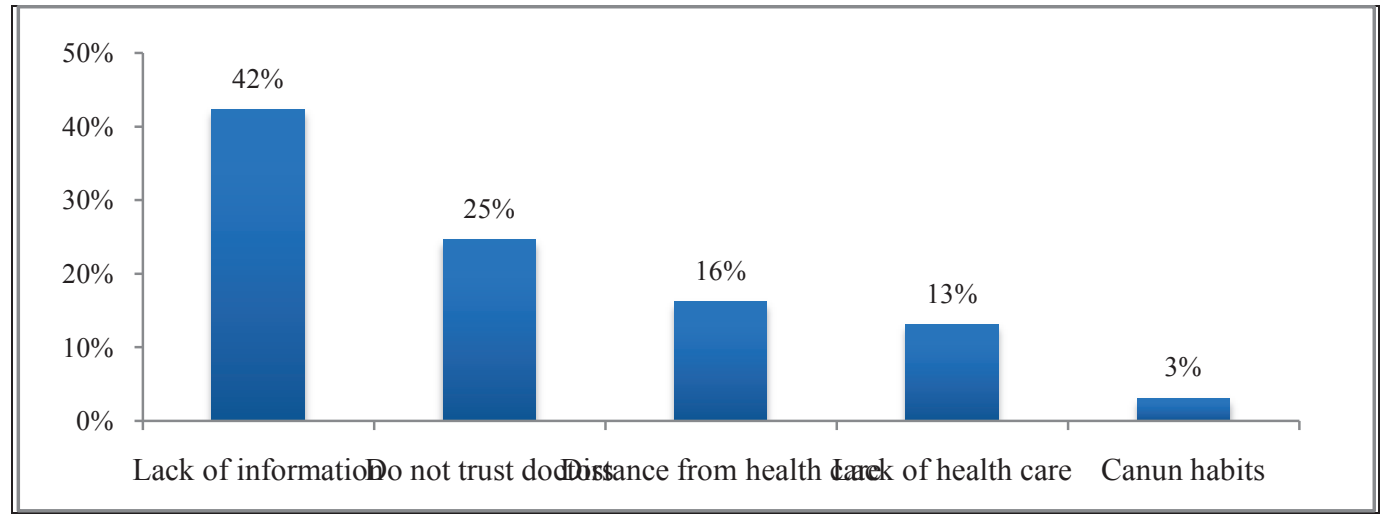

To improve health care for women, 49 percent of women interviewed think that the state is responsible, while one in four women believe that the main responsibility for improving the health service it's their own.

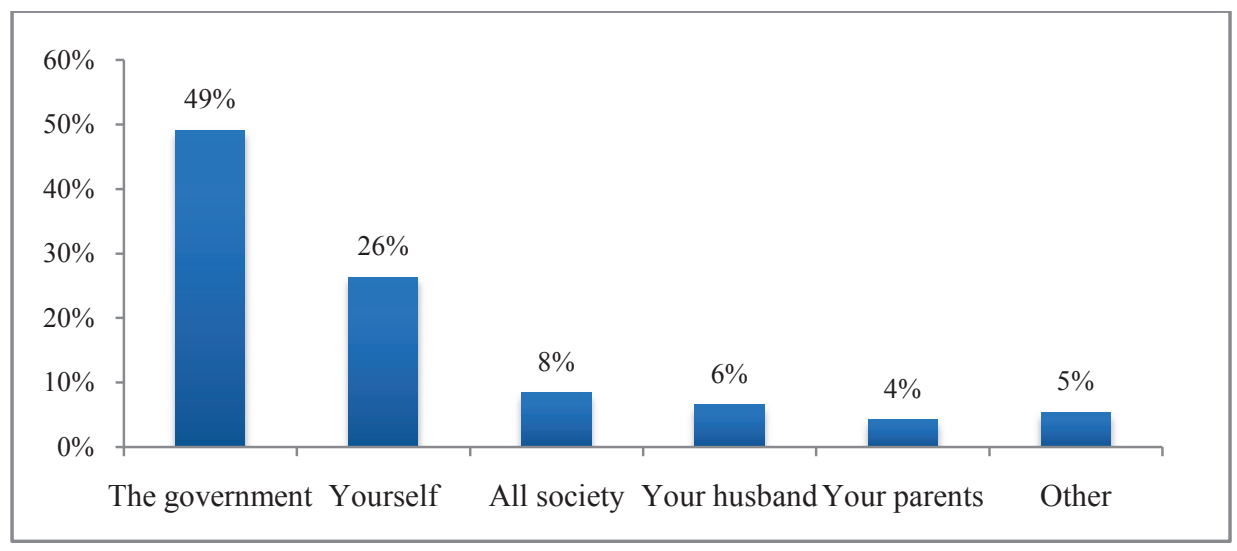

Opinions of women to improve their lives in the former swamp area converge mostly in opening opportunities for job. They refer to the role that should be played by the state to increase the employment of women. While a large proportion of women think that the opening of centers for women will help them to improve their lives.

\section{Here are some information on employment, leisure and income.}

37.4 percent of the women interviewed, aged 16 years and over stated that they are employed.

Of employed women, more than a third work in the private sector and 16 percent of them work in the public sector. While 18 percent of women are in self-employment (see Figure XX). 


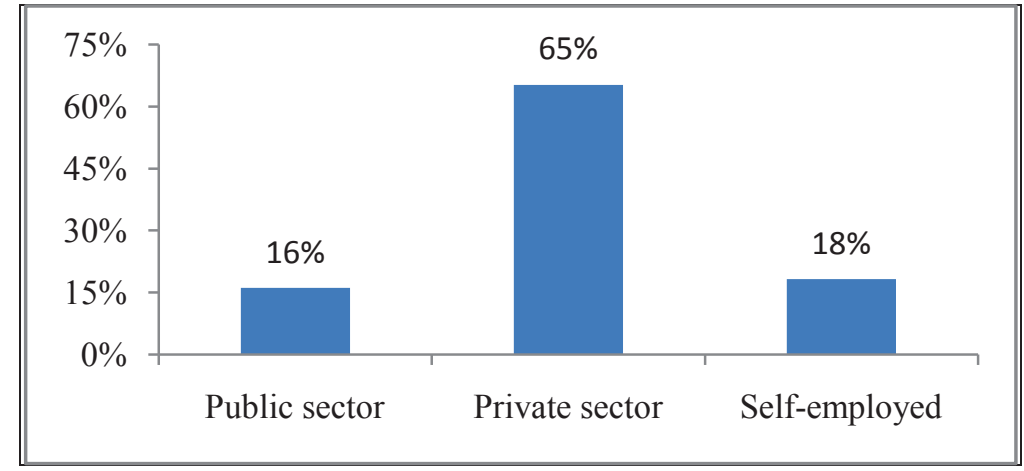

Over three in four women employed in former swamp area work full-time (76 percent), while the rest is engaged in parttime work. Regarding personal monthly income, 51 percent of women receive an income of 10.000-20.000 leke- which is lower than the minimum wage set by law they take monthly. A low percentage of women (5 percent) have an average monthly income below 10,000 leke.

Figure: Distribution of women according to the monthly personal income

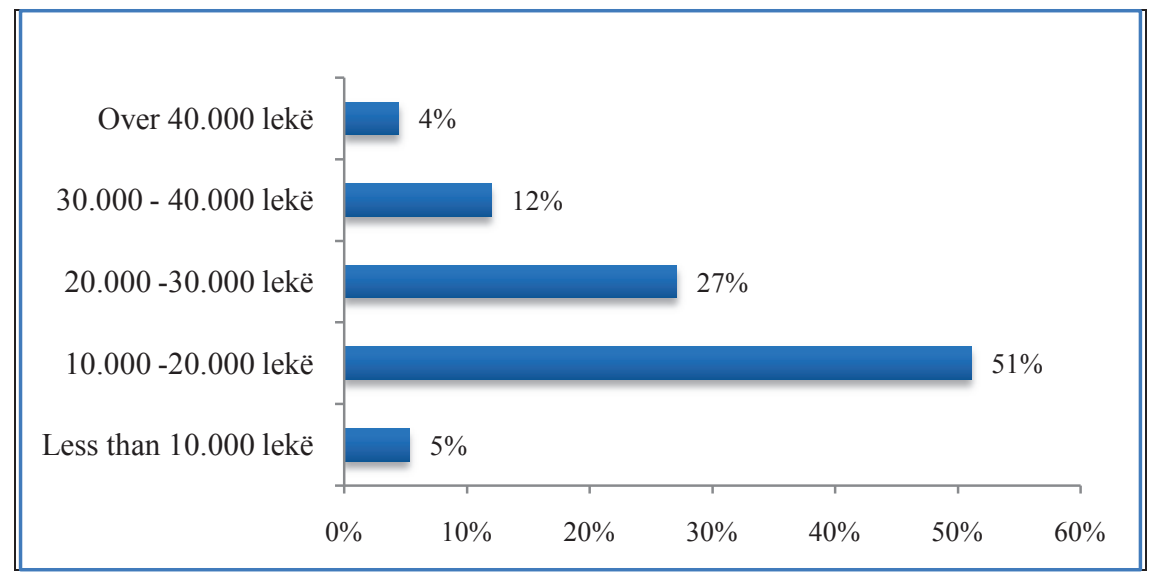

According to data collected in the study, it appears that the unemployment rate for women is about 28 percent in former swamp area.

By analyzing the reasons of being in the unemployment status (unemployed and economically inactive) was showed that 16 percent of women not in employment are desperately unemployed, so these women believe that there are no jobs available in the labor market (see Figure XX). While 10 percent of women not in employment stated that they are attending school and 6 percent are retired. What stands out is that the majority of women not in employment are outside the labor market because they need to raise children. 
Figure: Distribution of women by reason of which there are not employed.

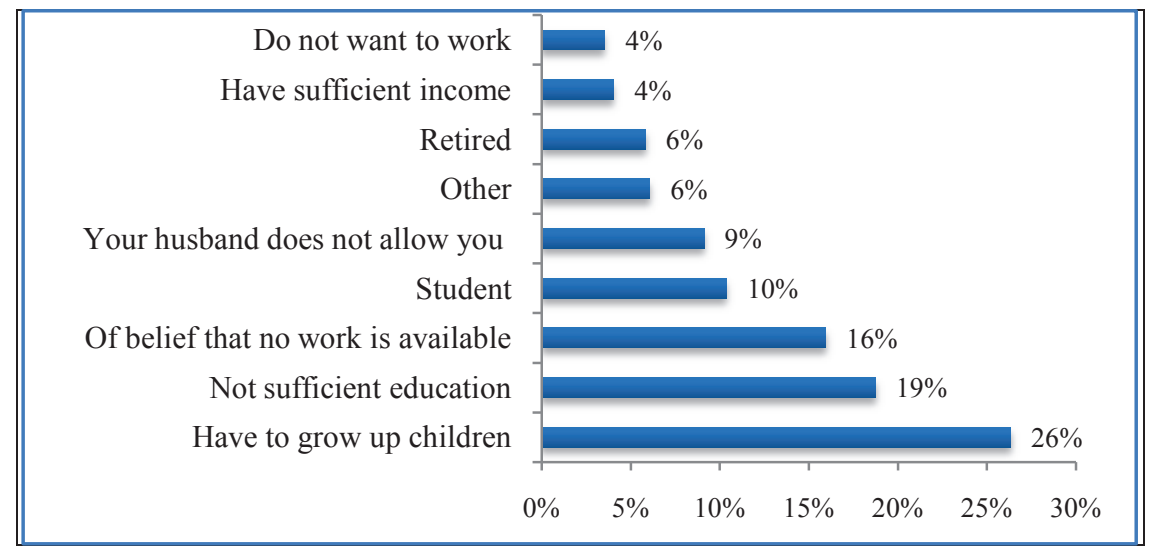

As for 19 percent of women not employed, another reason that prevents women to be part of the labor market is the lack of adequate education .

Figure: Distribution of households by average monthly income.

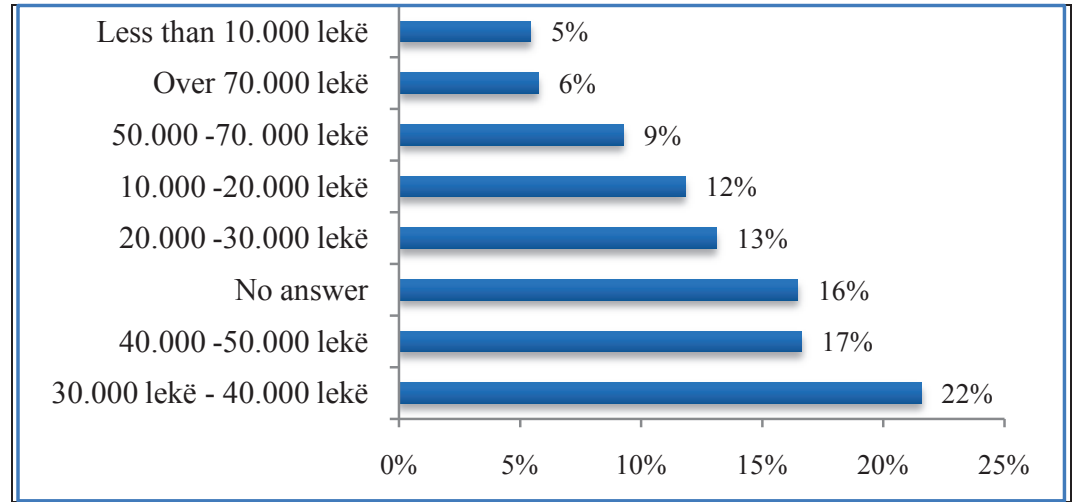

\begin{tabular}{|c|c|c|c|c|c|c|}
\hline \multirow{2}{*}{$\begin{array}{l}\text { It is considered your } \\
\text { opinion about: }\end{array}$} & Yes & No & $\begin{array}{l}\text { No } \\
\text { answer }\end{array}$ & Average & $\begin{array}{l}\text { Standard } \\
\text { deviation }\end{array}$ & Variance \\
\hline & \multicolumn{3}{|c|}{ In percentage } & & & \\
\hline Giving birth to a child & 62.92 & 11.09 & 25.99 & 0.87 & 0.03 & 0.75 \\
\hline Bringing up a child & 74.80 & 5.23 & 19.97 & 0.81 & 0.03 & 0.65 \\
\hline The house incomes & 62.28 & 19.18 & 18.54 & 0.79 & 0.03 & 0.62 \\
\hline Your employment & 68.78 & 18.54 & 12.68 & 0.71 & 0.03 & 0.50 \\
\hline Living place & 58.16 & 30.11 & 11.73 & 0.70 & 0.03 & 0.48 \\
\hline
\end{tabular}




\begin{tabular}{|l|l|l|l|l|l|l|l|l|l|}
\hline & $\begin{array}{l}\text { Very } \\
\text { important }\end{array}$ & \multicolumn{1}{l|}{$\begin{array}{l}\text { Importan } \\
\mathrm{t}\end{array}$} & $\begin{array}{l}\text { In } \\
\text { someway } \\
\text { important }\end{array}$ & $\begin{array}{l}\text { No } \\
\text { import } \\
\text { ant }\end{array}$ & $\begin{array}{l}\text { No } \\
\text { answer }\end{array}$ & $\begin{array}{l}\text { Averag } \\
\mathrm{e}\end{array}$ & $\begin{array}{l}\text { Standard } \\
\text { deviation }\end{array}$ & Variance \\
\hline & \multicolumn{2}{|l|}{ In percentage } & \multicolumn{2}{l|}{} & & & & \\
\hline $\begin{array}{l}\text { How important is the } \\
\text { women participation in } \\
\text { taking decisions }\end{array}$ & 63.87 & 29.32 & 4.28 & 1.11 & 1.43 & 0.76 & 0.03 & 0.57 \\
\hline & Always & Often & Sometimes & Never & $\begin{array}{l}\text { No } \\
\text { answer }\end{array}$ & $\begin{array}{l}\text { Averag } \\
\text { e }\end{array}$ & $\begin{array}{l}\text { Standard } \\
\text { deviation }\end{array}$ & Variance \\
\hline $\begin{array}{l}\text { Is it considered your } \\
\text { opinion about your } \\
\text { children? }\end{array}$ & 48.81 & 17.43 & 12.36 & 4.44 & 16.96 & 1.50 & 0.06 & 2.26 \\
\hline $\begin{array}{l}\text { Is it considered your } \\
\text { opinion regarding the } \\
\text { family's financial } \\
\text { affairs? }\end{array}$ & 38.19 & 22.98 & 28.37 & 6.02 & 4.44 & 1.13 & 0.05 & 1.28 \\
\hline & $\begin{array}{l}\text { Continuousl } \\
\text { y }\end{array}$ & Rarely & Sometimes & Never & $\begin{array}{l}\text { No } \\
\text { answer }\end{array}$ & $\begin{array}{l}\text { Averag } \\
\text { e }\end{array}$ & $\begin{array}{l}\text { Standard } \\
\text { deviation }\end{array}$ & Variance \\
\hline $\begin{array}{l}\text { Have you ever felt } \\
\text { violated? }\end{array}$ & 4.28 & 10.14 & 22.35 & 50.71 & 12.52 & 0.98 & 0.04 & 0.96 \\
\hline & You & $\begin{array}{l}\text { Your } \\
\text { parents }\end{array}$ & $\begin{array}{l}\text { Your } \\
\text { husband }\end{array}$ & State & Other & $\begin{array}{l}\text { Averag } \\
\text { e }\end{array}$ & $\begin{array}{l}\text { Standard } \\
\text { deviation }\end{array}$ & Variance \\
\hline $\begin{array}{l}\text { Which of the following } \\
\text { actors do you think is } \\
\text { more responsible for } \\
\text { your education? }\end{array}$ & 36.29 & 37.24 & 7.77 & 10.14 & 8.56 & 1.26 & 0.05 & 1.59 \\
\hline
\end{tabular}

\section{References}

Nielson, J. (1978). Sex in society:Perspectives on stratification. Bel-mont, CA: Wadsworth.

Huber, J., \& Spitze, G. (1983). Sex Stratification: Children, housework and jobs. New York: Academic Press.

Friedl, E. (1975). Men and women: An anthropologist's view. New York: Holt, Rinehart\&Winston.

George, D., (1925). London Life in the Eighteen-Centyry, London: Kegan Paul, Trench, Trubner \& Co., fq 208.

Mitchell, B. R., (1962). Abstrac of British Historical Statistics, Cambridge: Cambridge University Press.

Harris, M. (1997). Cannibals and kings: the origins of cultures. New York: Random House.

Fisher, E. (1980). Womans creation: Sexual evolution and the shaping of society. New York: McGraw Hill.

Lerner, G. (1986). The creation of the patriarchy. New York: Oxford.

Engels, F. (1986). The Origin of the Family, Private Property and the State, in Karl Marx and Frederick Engels: Selected Works, New York: International Publishers.

Davidoff, L. \& Hall, C., (1987). Family Fortunes: Man and Women of the English Middle Class, 1780-1850, University of Chicago Press.

Demos, J. (1986). Past, present and personal: the family and the life course in American history. New York: Basic Books.

Cherlin, A. (1983). Changing Family and household: Contemporary lessons from historical research. Annual Review of Sociology 9,5166.

Tilly, L. A., \& Scott, J. W. (1978). Women work, and the family. New York: Holt, Rinehart \& Winston.

INSTAT, Anketimi mbi Kushtet e Jeteses se Familjes, 2009.

Raporti Kombëtar i Pozicionit të Grave dhe i Barazisë Gjinore në Shqipëri 2011.

Grint, Keith, (2005). The sociology of Work (Sociologjia e Punës).Bot. III. Angli: Polity Press. 